\title{
ASSESSING THE AGRICULTURAL COMMODITIES TRANSPORTATION IN THE STATE OF MATO GROSSO: SCENARIOS DESTINED TO EXPORTATION
}

Tássia Faria de Assis ${ }^{1 *}$, Daniel Neves Schmitz Gonçalves ${ }^{1}$, Marcelino Aurélio Vieira da Silva ${ }^{1}$ 1 Programa de Engenharia de Transportes, Universidade Federal do Rio de Janeiro, 21941-914, Rio de Janeiro-RJ, Brasil

\author{
*tassiafa@hotmail.com
}

\section{ABSTRACT}

The purpose of study is to assess alternatives for commodities transportation, in the State of Mato Grosso, Brazil, by adopting a Data Envelopment Analysis (DEA) method. Therefore, we used three models, called traditional (VRS and CRS) and the Cross - Evaluation. The inputs were the freight rate, cost of accidents and
\end{abstract}

$\mathrm{CO} 2$ emissions, while the output was the weighted average speed of each alternative. The study evaluated the performance of seven macroregions. Results indicated the best alternatives for each microregion, in particular, the adoption of railway mode all over the transportation process was indicated considering all scenarios.

KEYWORDS: data envelopment analysis; performance analysis; agricultural commodities; transport.

\section{AVALIAÇÃO DO TRANSPORTE DE COMMODITIES AGRÍCOLAS NO ESTADO DE MATO GROSSO: CENÁRIOS DESTINADOS À EXPORTAÇÃO}

\section{RESUMO}

O objetivo do estudo é avaliar alternativas para o transporte de mercadorias, no Estado do Mato Grosso, adotando o método Data Envelopment Analysis (DEA). Portanto, utilizamos três modelos, denominados tradicional (VRS e CRS) e a Cross - Evaluation. Os insumos foram a taxa de frete, custo de acidentes e emissões de $\mathrm{CO} 2$, enquanto a saída foi a velocidade média ponderada de cada alternativa. O estudo avaliou o desempenho de sete macrorregiões. Os resultados indicaram as melhores alternativas para cada microrregião, em particular, a adoção do modo ferroviário em todo o processo de transporte foi indicada considerando todos os cenários.

PALAVRAS CHAVE: análise de envoltória de dados; análise de desempenho; commodities agrícolas; transporte 


\section{INTRODUCTION}

From the 80's, the advance of the Brazilian agricultural frontier was toward Central North Brazil, driven by rising international grain prices, combined with low prices of the land in the region, which provided an aggressive conversion of livestock to grain. However, there are challenges that must be overcome, such as low natural soil fertility and the precarious and costly logistics, resulting in high production and transportation costs (CONAB, 2007 and IPEA, 2000).

According to Brazil (2014), the spatial distribution of the transportation sector in Brazil reveals a predominance of road transport mode, and its concentration in the South Center region of the country, especially in São Paulo. What makes the main distant destination ports of the main production sites.

Therefore, since the main purpose of the transport activity is move products into the activity system, the spatial distribution of the sector must be efficient in order to generate greater competition, economies of scale and price reductions for agricultural products, as these aren't commonly consumed in the same place where they are produced (BATTLE, 2011).

According to the study conducted by CNT (2015), for agricultural bulk cargo such as soybeans and corn, the attributes that have influence on the choice of the transportation mode by shippers are in descending order: the lowest cost of freight, the increased supply of transport, the largest cargo security, increased reliability on time, less time spent in transit, greater availability of infrastructure, lower level of loss or damage and better quality infrastructure.

Moreover, from the importance attached to the indicators: freight cost, transit time, reliability and timeliness, we adopted as a premise for this study the assessment of the problem considering the government 's vision, which aims to offer better conditions for the use of the system, in an efficiently way, to facilitate the competitiveness between producers and carriers, since these are responsible for collections of foreign exchange for the country.

Despite the mentioned indicators are responsible for the economic prosperity in any country, there are other indicators that may generate other impacts to society: traffic congestion, environmental issues, security, and other factors (SAMIMI, MOHAMMADIAN AND KAWAMURA, 2010).

The purpose of this article is to assess through the application of the DEA, the alternative transport of agricultural commodities from the evaluation of soybean flow, determine the most efficient alternatives in each of the Mato Grosso State macroregions and propose efficient alternatives for each region or area of origin of the distribution process.

\section{DATA ENVELOPMENT ANALYSIS - DEA}

DEA, date envelopment analysis is a linear programming application for decision support in multidisciplinary problem, developed by Charnes et al. (1994), it's a non-parametric approach to treating units' performance evaluation problems, known as DMU of Decision Making Units (COOPER et al., 2007, LINS and CALÔBA, 2006). The determination of the relative efficiency of each DMU is performed by comparing it with the others, considering the relationship between the resources that are available (inputs) and results achieved (outputs).

Instead of the traditional parametric approach, the DEA optimizes each individual observation in order to determine a linear Frontier by comprising the set of DMU Pareto efficient (LINS and CALÔBA, 2006), wherein the located DMU index is $100 \%$. 
In this analysis, there are two classic models: the CCR or CRS (CHARNES et al., 1978; GARCIA et al., 2017), which takes into account the constant returns to scale, and the BCC or VRS model (BANKER et al., 1984), that considers variable returns scale, not assuming proportionality between inputs and outputs and assuming greater operational diversity (due to its more efficient units and different tradeoffs at the border) (LINS and CALÔBA, 2006). Both models allow free choice of the weights givens for the inputs and outputs of each DMU, which leads to the selection of the set of weights that maximize efficiency.

Since its inception, the DEA has been applied to solve several problems, thereby it has revealed some drawbacks, which according to ANGULO - MEZA and LINS (2002), are:

(i) Multiple optimal solutions for efficient DMUs weights scheme;

(ii) Deficiency discrimination of efficient DMUs, inconvenience occurs when the number of DMUs is small compared to the total number of analysis variables;

(iii) Inadequate weights generated by the model, which in most cases are not very adherent, providing zero weight (or too small) for important variables and high weights for variables with less importance.

To avoid these problems some techniques have been proposed by the specialized literature such as: Cross - Evaluation and the allocation weights. Proposed by Sexton (1986), Cross Evaluation DEA's main idea to preserve the idea not to include a priori information using DEA in an overall assessment of the DMU's, instead of self-assessment. An evaluation of the joint means, each DMU is evaluated according to the optimal weights scheme other DMU, to generate a matrix of cross - efficiencies, with a mean of all these efficiencies efficient cross (LINS and MEZA, 2000).

\section{MATERIALS AND METHODS}

\subsection{Approach of the problem}

The foregoing problem involves evaluating the efficiency of the agricultural commodity transportation alternatives soybeans drained from the Mato Grosso State to the main Brazilian ports.

Among the different types of agricultural commodity, the soybean stands to represent about $51 \%$ of the production of staple grains (cotton, corn and soybeans) the country (CONAB, 2015).

In Brazil, according to CONAB (2015) and ABIOVE (2015), soybean production in the $2013 / 2014$ harvest was approximately 86 billion tons, in which about $53 \%$ of the demand was destined for the foreign market, while about $43 \%$ was destined for processing in the domestic market, and only about $4 \%$ of the production was destined for the stock in warehouses. The proposed problem consists of seven macroregions distributed in the State of Mato Grosso. In each macroregion one municipality is selected, which are valued the most efficient transportation alternatives, allowing a process of flow through selection of the most viable production.

The seven macroregions of Mato Grosso were set to target the state under the macroeconomic point of view, in order to facilitate the data gathering and scale its agricultural economy shown in Figure 1. 


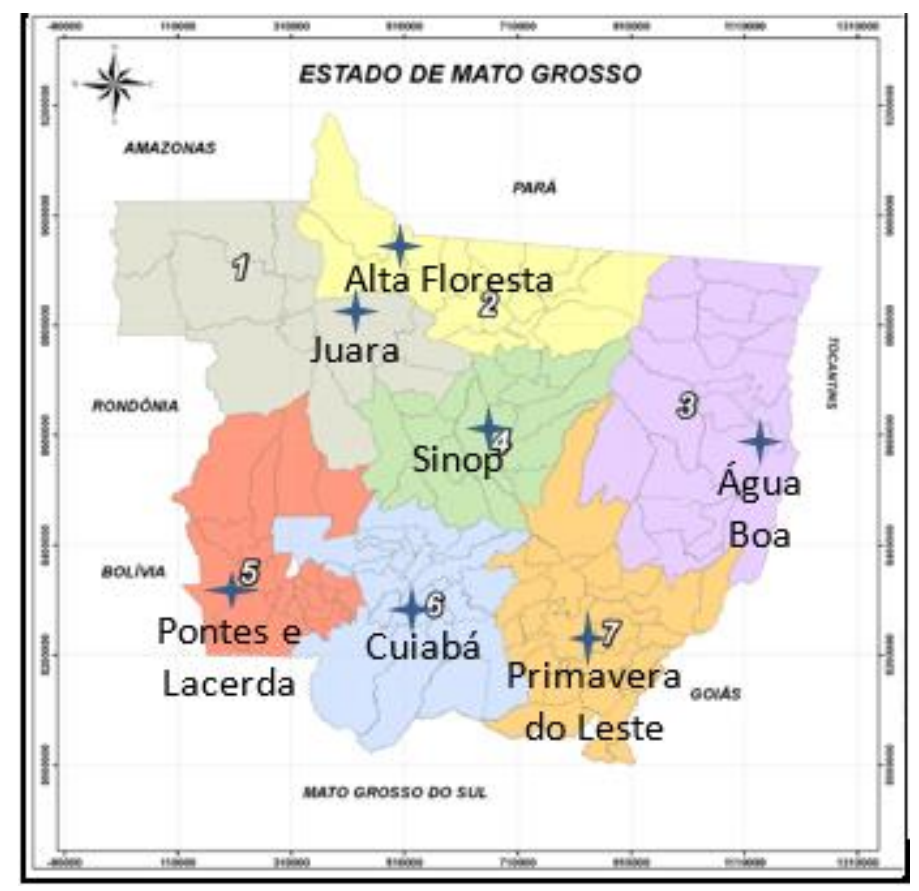

Figura 1: Division of Agrieconomic macroregions of Mato Grosso

Source: Adapted from IMEA (2010)

The Table 1 shows the macroregions along with the municipalities selected as distribution of each macroregion centers.

Table 1: Description of the strategic points of the problem

\begin{tabular}{lcc}
\hline Macroregion & Strategic city & Production of Macroregion (t) \\
\hline $1-$ Northwest & Juara & 1.674 .352 \\
\hline $2-$ North & Alta Floresta & 489.005 \\
\hline $3-$ Northeast & Água Boa & 3.746 .669 \\
\hline $4-$ Middle North & Sinop & 9.370 .372 \\
\hline $5-$ West & Pontes e Lacerda & 3.361 .853 \\
\hline $7-$ South Center & Cuiabá & 1.926 .788 \\
\hline - Southeast & Primavera do Leste & 5.722 .223 \\
\hline
\end{tabular}

Source: based on IMEA (2010), IMEA (2014), ABIOVE (2015)

The current production flow alternatives (Figure 2) of the Mato Grosso State macroregions considered an internal database as a source of information. 


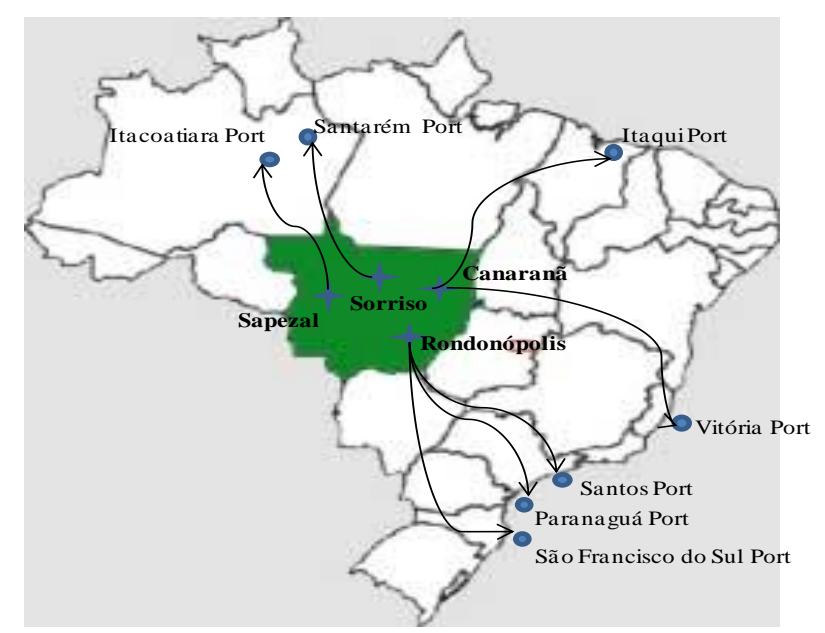

Figure 2: Location of the home counties and destination ports

Source: Author (2017)

Currently the flow of soybean production is performed considering ten alternatives, which are described in Figure 3.

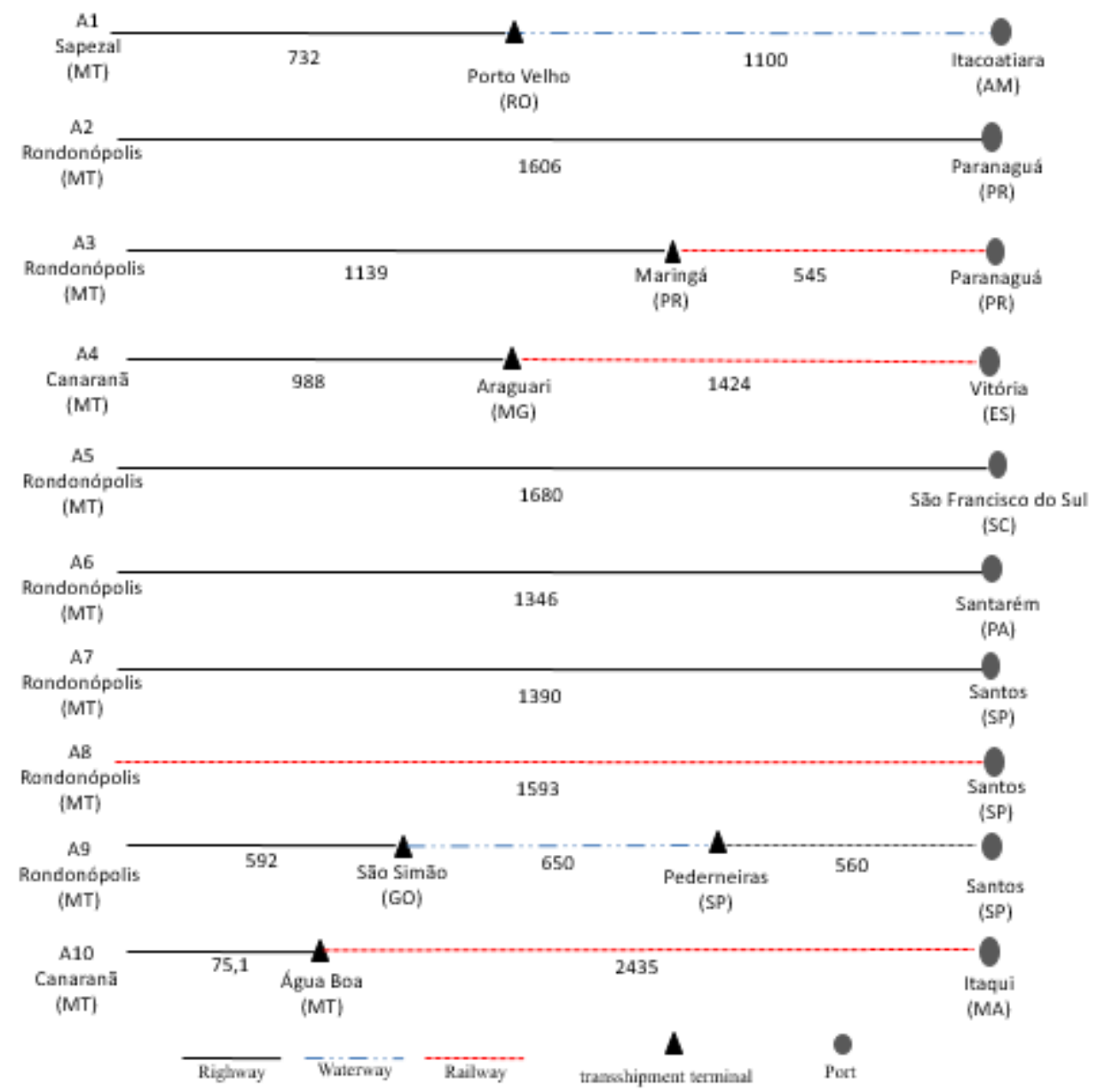

Figure 3: Current transportation alternatives of soybean flow

Source: Author (2017) 
Figure 4 shows a diagram consisted by the main variables considered in the study, which includes aspects, features and indicators found in the literature.

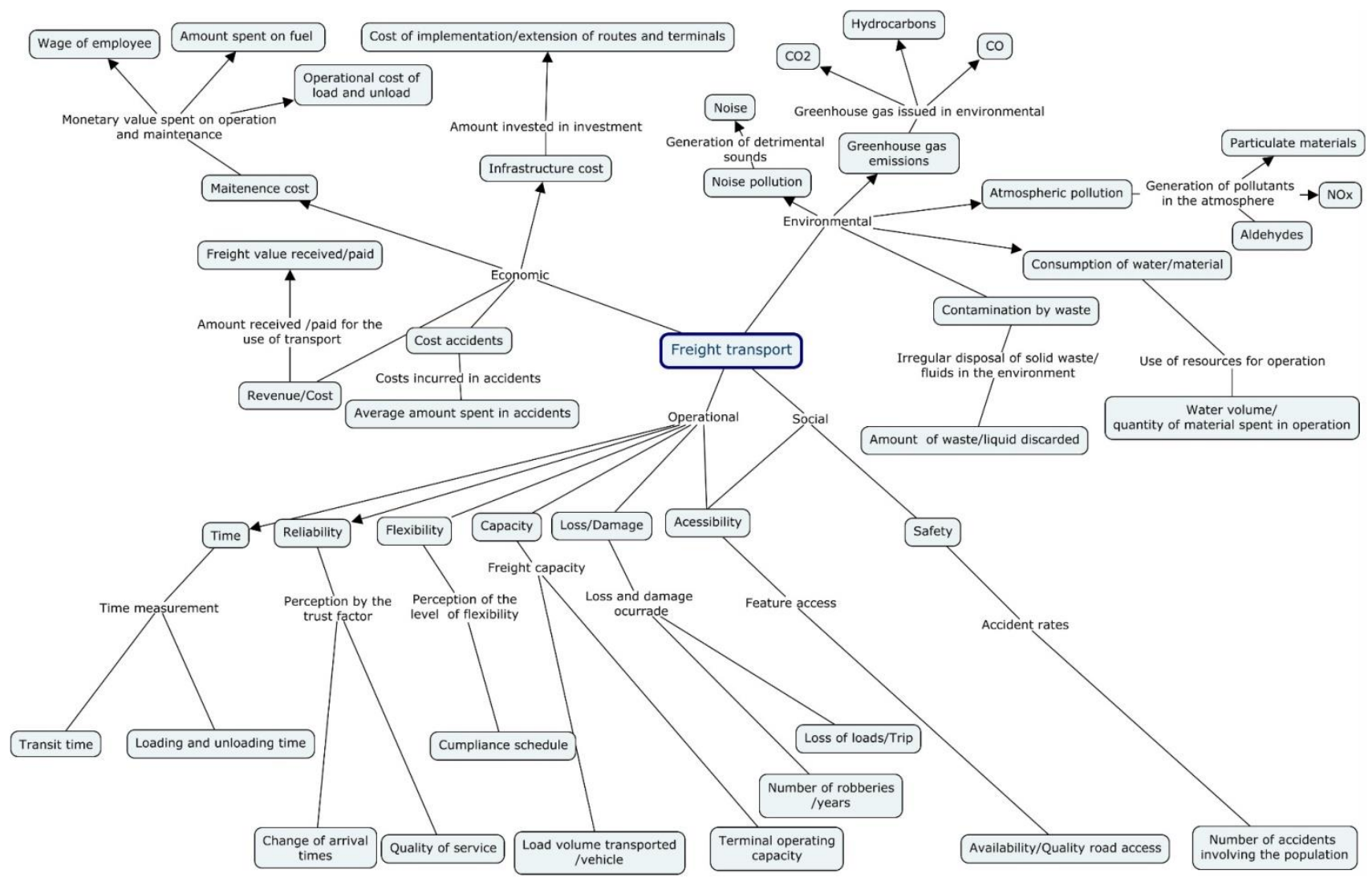

Figure 4: Diagram of the main variables used in cargo transport

Source: based on Cullinane and Toy (2000), Novaes et al. (2006), Leal Jr and D'Agosto (2011), Akasaka, and Silva Leal Jr (2015).

\subsection{Application of Analysis Envelopment DATA - DEA}

\subsubsection{Data submission}

Being DEA one multicriteria methodology of decision support, all quantitative indicators used can be treated as inputs or as outputs, depending strictly of the criteria being used in the design of modeling, and the coherence between them (LINS et al., 2007). The variables selected for the evaluation of the efficiency generated by the application of DEA are composed of the outputs weighted: average speed $(\mathrm{km} / \mathrm{h})$ (in each alternative and the undesirable outputs); freight rate (US\$); cost of accidents (US\$) and CO2 (kg).

As showed in Table 2, the data were defined based on the characteristics of each mode of transport, according to the distance between the parts of each mode from the available access roads, and the flow of production intended for export. Thus, the average speed $(\mathrm{km} / \mathrm{h})$ was nominated by "output", the freight for "input 1", the cost of accident by "input 2" and CO2 emissions by input 3.

Table 2: Values Presentation of inputs and outputs for each alternative 
Revista Produção e Desenvolvimento, v.4, n.2, p.31-41, 2018 http://revistas.cefet-rj.br/index.php/producaoedesenvolvimento
RPD

Revista Produção e Desenvolvimento Reseach in Production and Development

\begin{tabular}{|c|c|c|c|c|c|c|c|c|}
\hline Alternatives & Data & $\begin{array}{c}1 \\
\text { Juara }\end{array}$ & $\begin{array}{c}2 \text { Alta } \\
\text { Floresta }\end{array}$ & $\begin{array}{c}3 \text { Água } \\
\text { Boa }\end{array}$ & $\begin{array}{c}4 \\
\text { Sinop } \\
\end{array}$ & $\begin{array}{l}5 \text { Pontes e } \\
\text { Lacerda } \\
\end{array}$ & $\begin{array}{c}6 \\
\text { Cuiabá }\end{array}$ & $\begin{array}{c}7 \text { Primavera } \\
\text { do Leste }\end{array}$ \\
\hline \multirow{4}{*}{ A1 } & $\begin{array}{l}\text { Output } \\
(\mathrm{km} / \mathrm{h}) \\
\end{array}$ & 19,8 & 21,6 & 22 & 20,6 & 19,2 & 20,1 & 21 \\
\hline & $\begin{array}{c}\text { Input 1 } \\
\text { (millions US\$) }\end{array}$ & 179 & 63,3 & 497,4 & $1.019,2$ & 317,1 & 211,7 & 671,5 \\
\hline & $\begin{array}{c}\text { Input } 2 \\
\text { (millions US\$) }\end{array}$ & 54,9 & 19,4 & 152,5 & 312,4 & 97,2 & 64,9 & 205,9 \\
\hline & $\begin{array}{c}\text { Input } 3 \\
\text { (millions kg) }\end{array}$ & 52 & 20,4 & 167,0 & 327,6 & 95,9 & 62,7 & 216,2 \\
\hline \multirow{4}{*}{ A2 } & $\begin{array}{l}\text { Output } \\
(\mathrm{km} / \mathrm{h})\end{array}$ & 30 & 30 & 30 & 30 & 30 & 30 & 30 \\
\hline & $\begin{array}{c}\text { Input } 1 \\
\text { (millions US\$) } \\
\end{array}$ & 66,5 & 22,9 & 144,5 & 394,3 & 138,9 & 64,6 & 178,6 \\
\hline & $\begin{array}{c}\text { Input } 2 \\
\text { (millions US\$) }\end{array}$ & 1,6 & 0,7 & 4,6 & 12,4 & 4,4 & 2,0 & 5,7 \\
\hline & $\begin{array}{c}\text { Input } 3 \\
\text { (millions kg) }\end{array}$ & 68,5 & 27,8 & 174 & 470,5 & 166 & 76,6 & 216,4 \\
\hline \multirow{4}{*}{$\mathbf{A 3}$} & $\begin{array}{l}\text { Output } \\
(\mathrm{km} / \mathrm{h}) \\
\end{array}$ & 31,4 & 31,3 & 31,6 & 31,4 & 31,5 & 31,8 & 31,9 \\
\hline & $\begin{array}{c}\text { Input 1 } \\
\text { (millions US\$) }\end{array}$ & 92,3 & 23,4 & 148,7 & 405,0 & 142,7 & 66,7 & 185,2 \\
\hline & $\begin{array}{c}\text { Input } 2 \\
\text { (millions US\$) }\end{array}$ & 2,4 & 0,6 & 3,9 & 10,7 & 3,8 & 1,7 & 4,7 \\
\hline & $\begin{array}{c}\text { Input } 3 \\
\text { (millions kg) }\end{array}$ & 100,5 & 25 & 152,3 & 416,3 & 146,6 & 65,4 & 183,3 \\
\hline \multirow{4}{*}{ A4 } & $\begin{array}{l}\text { Output } \\
(\mathrm{km} / \mathrm{h}) \\
\end{array}$ & 22,9 & 22,5 & 20,2 & 22,2 & 22,9 & 21,9 & 21,4 \\
\hline & $\begin{array}{c}\text { Input } 1 \\
\text { (millions US\$) } \\
\end{array}$ & 108,8 & 28,2 & 158,9 & 512,6 & 200,9 & 101,0 & 290,3 \\
\hline & $\begin{array}{c}\text { Input } 2 \\
\text { (millions US\$) }\end{array}$ & 3,2 & 0,6 & 3,2 & 11,3 & 4,7 & 2,2 & 5,9 \\
\hline & $\begin{array}{c}\text { Input } 3 \\
\text { (millions kg) }\end{array}$ & 121 & 25,4 & 131,2 & 456,4 & 187,9 & 89,2 & 240,4 \\
\hline \multirow{4}{*}{ A5 } & $\begin{array}{l}\text { Output } \\
(\mathrm{km} / \mathrm{h}) \\
\end{array}$ & 30,0 & 30,0 & 30,0 & 30,0 & 30,0 & 30,0 & 30,0 \\
\hline & $\begin{array}{c}\text { Input } 1 \\
\text { (millions US\$) }\end{array}$ & 115,6 & 23,5 & 149,3 & 406,3 & 143,2 & 67,0 & 186,0 \\
\hline & $\begin{array}{c}\text { Input } 2 \\
\text { (millions US\$) }\end{array}$ & 3,5 & 0,8 & 4,8 & 12,8 & 4,5 & 2,1 & 6,0 \\
\hline & $\begin{array}{c}\text { Input } 3 \\
\text { (millions kg) }\end{array}$ & 131,4 & 28,6 & 180,0 & 485,6 & 171,4 & 79,7 & 225,7 \\
\hline \multirow{4}{*}{ A6 } & $\begin{array}{l}\text { Output } \\
(\mathrm{km} / \mathrm{h}) \\
\end{array}$ & 30,0 & 30,0 & 30,0 & 30,0 & 30,0 & 30,0 & 30,0 \\
\hline & $\begin{array}{c}\text { Input } 1 \\
\text { (millions US\$) } \\
\end{array}$ & 77,9 & 17,4 & 148,7 & 257,5 & 132,6 & 68,6 & 217,7 \\
\hline & $\begin{array}{c}\text { Input } 2 \\
\text { (millions US\$) }\end{array}$ & 2,1 & 0,5 & 4,4 & 7,7 & 4,0 & 1,9 & 6,5 \\
\hline & $\begin{array}{c}\text { Input } 3 \\
\text { (millions kg) }\end{array}$ & 80,1 & 18,6 & 167,7 & 292,2 & 149,5 & 73,3 & 246,0 \\
\hline \multirow{4}{*}{ A7 } & $\begin{array}{l}\text { Output } \\
(\mathrm{km} / \mathrm{h})\end{array}$ & 30,0 & 30,0 & 30,0 & 30,0 & 30,0 & 30,0 & 30,0 \\
\hline & $\begin{array}{c}\text { Input } 1 \\
\text { (millions US\$) }\end{array}$ & 80,3 & 22,0 & 137,9 & 377,8 & 133,0 & 61,2 & 168,5 \\
\hline & $\begin{array}{c}\text { Input } 2 \\
\text { (millions US\$) }\end{array}$ & 2,2 & 0,7 & 4,1 & 11,3 & 4,0 & 1,8 & 5,0 \\
\hline & $\begin{array}{c}\text { Input } 3 \\
\text { (millions kg) } \\
\end{array}$ & 85,8 & 25,5 & 156,3 & 426,3 & 150,2 & 67,5 & 189,5 \\
\hline \multirow{4}{*}{ A8 } & $\begin{array}{l}\text { Output } \\
(\mathrm{km} / \mathrm{h}) \\
\end{array}$ & 36,4 & 36,1 & 37,4 & 36,9 & 37,0 & 38,7 & 39,2 \\
\hline & $\begin{array}{c}\text { Input } 1 \\
\text { (millions US\$) } \\
\end{array}$ & 73,3 & 20,1 & 123,4 & 341,8 & 120,0 & 53,7 & 146,5 \\
\hline & $\begin{array}{c}\text { Input } 2 \\
\text { (millions US\$) }\end{array}$ & 2,1 & 0,4 & 2,1 & 6,1 & 2,1 & 0,7 & 1,8 \\
\hline & $\begin{array}{c}\text { Input } 3 \\
\text { (millions kg) }\end{array}$ & 80,2 & 17 & 91,0 & 262,8 & 91,5 & 33,9 & 89,6 \\
\hline \multirow{2}{*}{ A9 } & $\begin{array}{l}\text { Output } \\
(\mathrm{km} / \mathrm{h})\end{array}$ & 23,6 & 24,0 & 22,7 & 23,2 & 23,1 & 21,6 & 21,2 \\
\hline & $\begin{array}{c}\text { Input } 1 \\
\text { (millions US\$) } \\
\end{array}$ & 306 & 69 & 428 & L.178,20 & 414,2 & 188,3 & 516,7 \\
\hline
\end{tabular}




\begin{tabular}{|c|c|c|c|c|c|c|c|c|}
\hline & $\begin{array}{c}\text { Input } 2 \\
\text { (millions US\$) }\end{array}$ & 2,3 & 0,5 & 2,8 & 8,0 & 2,8 & 1,1 & 3,0 \\
\hline & $\begin{array}{c}\text { Input } 3 \\
\text { (millions kg) } \\
\end{array}$ & 92,2 & 21,1 & 122,2 & 341,0 & 119,6 & 50,0 & 137,4 \\
\hline \multirow{4}{*}{ A10 } & $\begin{array}{l}\text { Output } \\
(\mathrm{km} / \mathrm{h})\end{array}$ & 29,2 & 29,2 & 28,9 & 29,2 & 29,2 & 29,1 & 29,1 \\
\hline & $\begin{array}{c}\text { Input } 1 \\
\text { (millions US\$) }\end{array}$ & 91,4 & 26,2 & 127,5 & 474,4 & 187,2 & 93,2 & 267,0 \\
\hline & $\begin{array}{c}\text { Input } 2 \\
\text { (millions US\$) }\end{array}$ & 2,2 & 0,5 & 1,4 & 7,8 & 3,5 & 1,5 & 3,8 \\
\hline & $\begin{array}{c}\text { Input } 3 \\
\text { (millions kg) } \\
\end{array}$ & 86,6 & 19,7 & 73,6 & 346,3 & 148,4 & 66,5 & 173,2 \\
\hline
\end{tabular}

Note: 1 US $\$=\mathbf{R} \$ 3.2620$

\subsubsection{Method of Application}

In this study we will use the CRS and VRS models, both oriented input with multiplier and envelope template, forming a total of three tests, as follows: CRS without restriction to weights, VRS without restriction weights and CRS with cross-validation.

Was used the DREAM software, version 2.0, developed by DEA Group - Operational Research and Psigma Problem Structuring and Indicators Group for Modeling and Assessment (LINS et al., 2004).

\section{RESULTS AND DISCUSSION}

The methods adopted for the evaluation of alternatives were applied to the seven macroregions, totaling seventy results of returns on each method. From the application software IDEAL version 2.0, we obtained the results shown in Table 3.

Table 3: Final result of efficient DMUs for each macroregion

\begin{tabular}{lccc}
\hline Macroregion & CRS & VRS & Cross-evaluation \\
\hline 1- Juara & DMU 8, 2 e 1 & DMU 8, 2 e 1 & DMU 8 \\
\hline 2- Alta Floresta & DMU 8 & DMU 8e 6 & DMU 5, 8 e 6 \\
\hline 3- Água Boa & DMU 8 e 10 & DMU 8 e 10 & DMU 8 \\
\hline 4- Sinop & DMU 8 e 6 & DMU 8 e 6 & DMU 8 e 6 \\
\hline 5- Pontes e Lacerda & DMU 8 & DMU 8 e 1 & DMU 8 \\
\hline 6- Cuiabá & DMU 8 & DMU 8 e 5 & DMU 8 \\
\hline 7 - Primavera do Leste & DMU 8 & DMU 8 & DMU 8 \\
\hline
\end{tabular}

Where in, the most efficient DMUs are described in descending order from left to right. As the DMU 8 is excellent in all macroregions and this alternative is destined for the port of Santos in the State of São Paulo starts with the premise that it is not sufficient to meet the production demand generated by the Mato Grosso State, because it is the largest source of concentration of the country's production flow. 
The alternative A8 stands out from the others, as among the selected input and output showed better results as those generated values, being benefited by the use of rail transport mode in most of the route, besides the railway infrastructure compared to the other alternatives has advantages in terms of maximum permissible speed. The results without the DMU 8 is shown in Table 4.

Table 4: Final result of efficient DMUs for each macroregion without DMU 8

\begin{tabular}{lccc}
\hline \multicolumn{1}{c}{ Macroregion } & CRS & VRS & Cross-evaluation \\
\hline Juara & DMU 2 & DMU 1, 2 e 3 & DMU 2 \\
\hline Alta Floresta & DMU 6 e10 & DMU 1, 6 e 9 & DMU 5 \\
\hline Água Boa & DMU 10 & DMU 10 e 3 & DMU 10 \\
\hline Sinop & DMU 6 & DMU 1 e 6 & DMU 6 \\
\hline Pontes e Lacerda & DMU 1 e 6 & DMU 1, 6 e 10 & DMU 6 e 7 \\
\hline Cuiabá & DMU 3, 7, 9 e 10 & DMU 3, 7, 9 e 10 & DMU 3 \\
\hline Primavera do Leste & DMU 3, 7 e 10 & DMU 3, 7, 9 e 10 & DMU 3 \\
\hline
\end{tabular}

Source: Author (2017)

Due to the application of the method by cross- evaluation assign weights to all inputs and outputs the final result is achieved from it.

Table 4 presented, disregarding the DMU 8, showed new efficient alternatives such as alternative 2 in Macroregion 1, the A5 alternative in Macroregion 2, the alternative A10 in Macroregion 3, alternative A6 Macroregion 4 alternatives 6 and 7 in Macroregion 5 and alternative A3 in Macroregion 6 and Macroregion 7.

Based on all scenarios, it was possible to establish the best alternatives for each macroregion, as follows:

- Macroregion 1: alternative A2 and A8 as auxiliary alternative the alternative, A1 and A3;

- Macroregion 2: Alternative A5 and instead help alternative A6 and A9;

- Macroregion 3: Alternative A10 and instead help the alternative A8 and if there are improvements to $\mathrm{A} 3$ alternative too;

- Macroregion 4: Alternative A6 and alternative A1 as an auxiliary;

- Macroregion 5: Alternative A6 and A7 alternatives, A8 and A10 as auxiliaries;

- Macroregion 6: Alternative A3 and A7 alternatives, A8, A9 and A10 as auxiliaries;

- Macroregion 7: Alternative A3 and A7 alternatives, A8, A9 and A10 as auxiliary alternatives.

Generically the superior performance of the prominent alternative is justified, in most cases, by the location of origin and destination, percentage of the stretch traveled by each mode, path, load flow and infrastructure. 


\section{CONCLUSIONS}

The application of DEA identified the most efficient alternatives for each macroregion studied in order to achieve the objective. Traditional models of DEA were not viable for solving the problem, it is necessary to use another model, such as the cross- evaluation.

It was also possible to identify auxiliary transport alternatives for each macroregion, since the increase in soybean production is in an ongoing trend, which may exceed the capacity of the most common alternative.

The mode of transport was not the predominant factor in more efficient alternatives, such as expected, in which the influence factors for all geographical regions were as previously mentioned the location of origin, port location, percentage of the stretch travelled by each mode, path, load flow and infrastructure. For future studies, it is suggested an assessment, or benchmarks, of the inefficient alternatives in order to increase their performance, by the use of other indicators such as, terminal capacity, operating costs, transshipment time and issuance of other pollutants.

As indicated, the study of new indicators is necessary to identify potential alternatives using modes of transport that require economic and environmental studies, being competitive with current alternatives, aiming to reach ports located in areas that are not being considered so far.

\section{REFERENCES}

ABIOVE - Associação Brasileira das Industrias de Óleos Vegetais. Acessado em Janeiro de 2015. Disponível em: < http://www.abiove.org.br>.

AKASAKA, Y, SILVA, M. A. V., LEAL JR, I. C. Procedimento de escolha e análise de alternativas de transporte para exportação de bioetanol no Brasil. Journal of Transport Literature. v. 9. n. 1. p. 55-59, 2015

ANGUlo MEZA, L., LINS, M.P.E. A Análise Envoltória de Dados através do uso do Frontier Analyst. Pesquisa Operacional, v. 19, p. 287-293, 2000.

ANGULO MEZA, L., LINS, M.P.E. Modelos multiobjetivo para determinação de alvos na Análise Envoltória de Dados. Anais... XXXIV Simpósio Brasileiro de Pesquisa Operacional, Outubro, Rio de Janeiro, 2002.

BANKER, R.D.; CHARNES, A.; COOPER, W.W. Some models for estimating technical scale inefficiencies in data envelopment analysis. Management Science, v. 30, n. 9, p. 1078-1092, 1984.

BAtAlHA, M. O. Gestão Agroindustrial. Grupo de Estudos e Pesquisas Agroindustriais. Editora: São Paulo. $3^{\circ}$ ed. v1. 2011.

BRASIL - Portal Brasil. IBGE mapeia a infraestrutura dos Transportes no Brasil. Infraestrutura. Logística, 2014.

CHARNES, A.; COOPER, W.W. E RHODES, E. Measuring the Efficiency of Decision Making Units. European Journal of Operational Research, v.2, n.6, p. 429-444, 1978.

CNT - Confederação Nacional de Transporte. Entraves logísticos ao escoamento de soja e milho. Transporte \& Desenvolvimento. Brasília, 2015.

CONAB - Companhia Nacional de Abastecimento. 2007. Corredores de escoamento da produção agrícola: Corredor da Rodovia BR-163.

CONAB - Companhia Nacional de Abastecimento. Série histórica das safras. 2015. Disponível em: < http://www.conab.gov.br>.

COOPER, W. W.; SEIFORD, L. M. E TONE, K. Data envelopment analysis-A comprehensive text with models, applications, references and DEA-solver software (2nd Ed.). Berlin: Springer.

CORREA, V. H. C.; RAMOS, P. A precariedade do transporte rodoviário brasileiro para o escoamento da produção de soja do Centro-Oeste: Situação e Perspectivas. RESR, Piracicaba, SP, v. 48, n.2, p.447-472, 2010.

CULLINANE, K.; TOY, N. Identifying influential attributes in freight route/mode choice decisions: a content analysis. Transportation Research Part E, n.36, p.41-53, 2000. 
GARCIA, B.T.G., SILVA, M.A.V., FREITAS, M. A. V. Análise da eficiência na geração de resíduos sólidos nos terminais de carga geral brasileiro utilizando DEA. Revista Produção e Desenvolvimento, v.3, n.1, p.60-79, 2017.

IMEA - Instituto Matogrossense de Economia Agropecuária. Mapa de Macrorregiões do IMEA, 2010

IPEA - Instituto de Pesquisa Econômica Aplicada. Padrões regionais de crescimento da produção de grãos no Brasil e o papel da região Centro-Oeste. Ministério do Planejamento, orçamento e gestão, 2000.

LEAL JR, I. C., D’AGOSTO M. A. Modal choice for transportation of hazardous materials: the case of land modes of transport of bio-ethanol in Brazil. Journal of Cleaner Production. v.19. p.229-240, 2011.

LINS, M. E.; LOBO, M. S. C.; SILVA, A. C. M.; FISZMAN, R.; RIBEIRO, V. J. P. O uso da Análise Envoltória de Dados (DEA) para avaliação de hospitais universitários brasileiros. Ciência \& Saúde Coletiva, Rio de Janeiro, v. 12, n. 4, p. 985-998, 2007.

LINS, M. P. E.; CALÔBA, G. Programação Linear com aplicações em teoria dos jogos e avaliação de desempenho. Editora Interciência, Rio de Janeiro, 2006.

NOVAES, A. G., GONÇALVES, B. S., COSTA, M. B., SANTOS, S. Rodoviário, ferroviário ou marítimo de cabotagem? O uso da técnica de preferência declarada para avaliar a intermodalidade no Brasil. TRANSPORTES, v. XIV, n. 2, p. 11-17, 2006.

ROLL, Y. e GOLANY, B. Alternate Methods of Trating Factor Weights in DEA. Omega Int. Journal of Management Science, Great Britain, v.21, n.1, p.99-109, 1993.

SAMIMI, A.; MOHAMMADIAN, A.; KAWAMURA, K. Behavioral freight movement modeling. Workshop W2: Behavioral Paradigms for Modeling Freight Travel Decision-Making. The 12th International Conference on Travel Behaviour Research Jaipur, Rajasthan. India. 2010.

SEXTON, T. R. Measuring Efficiency: An Assessment of Data Envelopment Analysis. 32.ed. San Francisco: JosseyBass, 1986. 